\title{
Effect of Traditional Cattle Farming Systems on Farmer Knowledge, Cattle Performances and Agribusiness Potential in West New Guinea-Papua Barat Province, Indonesia
}

\author{
Deny A. Iyai ${ }^{1,2}$, Desni T. R. Saragih ${ }^{1}$, Frandz P. Rumbiak ${ }^{1}$ \\ ${ }^{1}$ Department of Animal Production, Faculty of Animal Sciences, Papua University, Jl, Gunung Salju, Amban, Manokwari, Papua Barat \\ Province, Indonesia \\ ${ }^{2}$ Perumahan Dosen, Papua University, Jl, Tugu Jepang, Amban, Manokwari, Papua Barat, Indonesia
}

Email address:

da.iyai@yahoo.com (D. A. Iyai)

To cite this article:

Deny A. Iyai, Desni T. R. Saragih, Frandz P. Rumbiak. Effect of Traditional Cattle Farming Systems on Farmer Knowledge, Cattle Performances and Agribusiness Potential in West New Guinea-Papua Barat Province, Indonesia. Animal and Veterinary Sciences. Vol. 4, No. 1, 2016, pp. 5-10. doi: 10.11648/j.avs.20160401.12

\begin{abstract}
Cattle have been long time introduced in Papua. However adaptation to raise cattle has been unpredictable. An explorative field study using participatory analysis was done in fifteen villages to comprehensively understand the dynamic of cattle performances. Cattle farming system was classified in to three sizes, i.e. small-medium- and large systems. Analyses of data were using Anova and Kruskal-Wallis. The finding of this research was that the three cattle farming sizes were similar in many components of good agricultural practices $(\mathrm{p}>0.05)$. No wide gap was found in line with farmers, cattle and economical performances. Tropical livestock unit of West New Guinea was low and has possibility to be increased due to agribusiness potential. Lack of good agricultural practices should be narrowed down by better services of government and other related stakeholders.
\end{abstract}

Keywords: Cattle, Farmer Performances, Traditional Farming System, Agribusiness, West New Guinea

\section{Introduction}

Cattle is one of the exotic and conventional animal agriculturesin Asia (Devendra, 2007), Indonesia (Utomo danWidjaya, 2007) and Papua (Hartono and Widayati, 2011). Its rank is in the third place after pigs, and native chicken. During the Ducth administration several animal agricultures had been introduced since 1963, such as pigs, rabbit, chicken, and dairy cattle. In alternated administration of Ducth to Indonesia, several animal agricultures have been introduced since 1972, i.e. Bali cattle, goat, and duck. Under Indonesia administration as well livestock projects were established by designing several relevant and related programs (Bahri et al., 2004). Programs a suchwere president aid, low developed villages program (Kusnadi, 2008), and direct community aid. Since then, less information concerning cattle farming productivity has been reported yet. This induces development of livestock farming systems are growing behind national average productivity. Figures of cattle population in Papua
Barat and Manokwariare 37.212 head and 20.829 head. Due to the third places of cattle, local Papuan farmers raise cattle with low effort and support by using their local resources. It is predicted that their livelihood improved slower than that of non Papuan ethnic (transmigrates). The cattle which are raised by each farmer in Papua Barat is less than counted by Hartono and Widayati (2011). Unskilled and less experiences of local Papuan farmers bring difficulty and unease to raise cattle. Therefore although it has been long time since introduced, adaptation to raise cattle is still unpredictable. Due to unskilled raising cattle, local Papuan is prone to keep cattle with low even no external and internal inputs. This in turn induces declined productivity of farmers and cattle performances. Because of introduce with less even no extension program, local Papuan farmers have no experiences. This is a common situation experienced by Papuan livestock farmers (Supriadi, 2008). They even do not know what does nutrition composition offered for cattle (Haryanto, 2009; Nulik and Hau, 2005) and what 
management is needed to raise cattle (Sudaryanto and Jamal, 2000). The latter becomes so important and plays a role in designing and applying resources. Several livestock farming systems have been identified by Iyai and Chrisostomus (2013) and the focus of this article is on traditional cattle farming systems. The objective of this study was to picturing performances of several classes of cattle farming systems in Manokwari. This study was done to specifically seekhow well traditional cattle farming systems run their farms using inputs, outputs and what happen in the process inside the farms (Sudaryanto and Jamal, 2000).

\section{Materials and Methods}

An explorative-field case study was done in Manokwari regency and involved six districts, i.e. Northern Manokwari district, Eastern Manokari District, Western Manokwari district, Warmare district, Prafi district and Masni district. Manokwari regency, which has a total area of $14.445 \mathrm{~km}^{2}$, possesses a population of around 161.000 inhabitants with a density of 11.51 heads $\mathrm{km}^{-1}$, and is located at $132^{\circ} 30^{\prime}-$ $134^{\circ} 45^{\prime}$ East Meridian and $0^{\circ} 20^{\prime}-2^{\circ} 25^{\prime}$ South latitude.

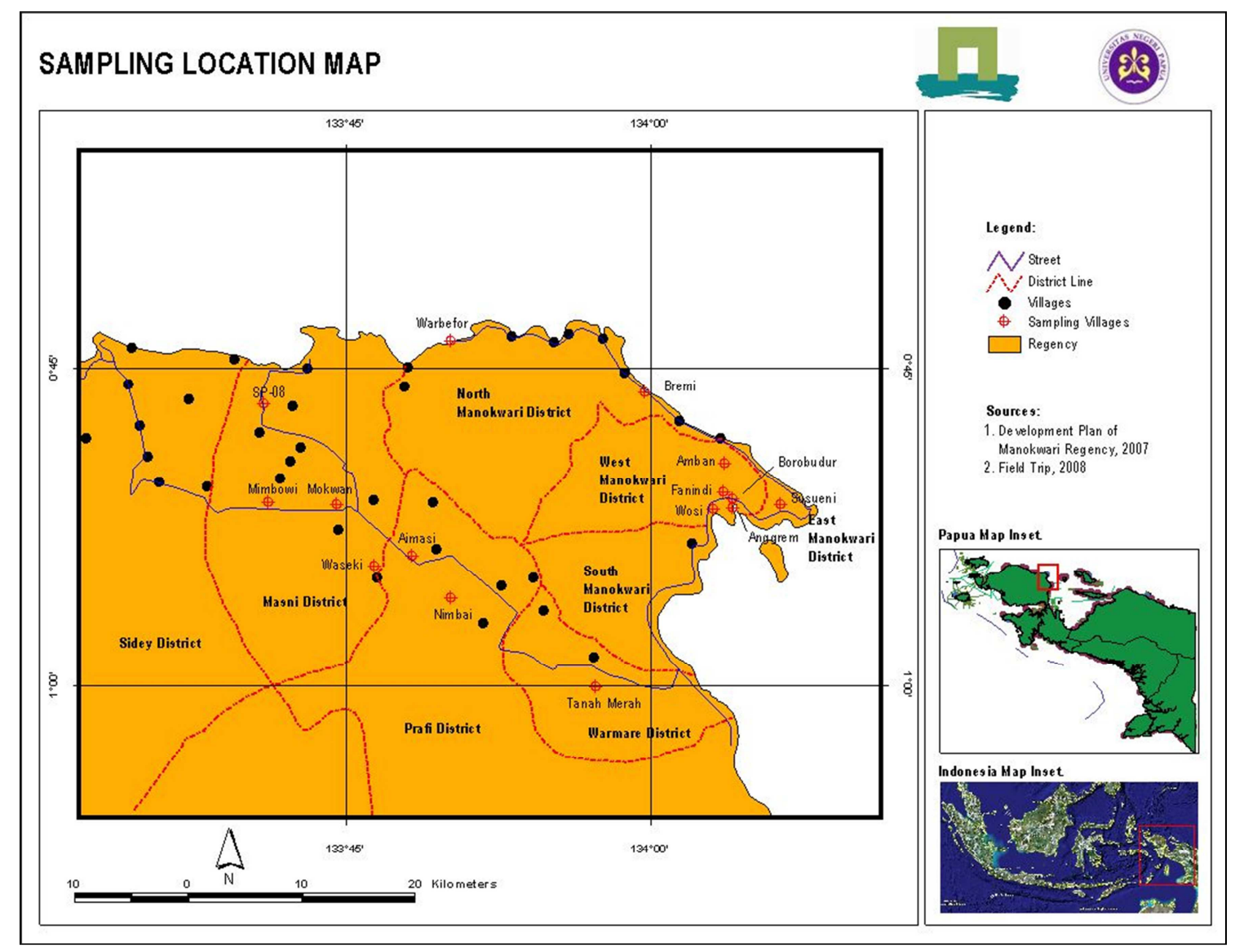

Figure 1. Sampling location of cattle farmers' survey in Manokwari, Papua barat-West New Guinea.

The population in Manokwari is growing in both urban and rural areas, especially in transmigration areas, such as Prafi and Masni districts. Respondents chosen were guided by local extensionists, originated from 14 villages, i.e..Warbefor, Bremi, Susweni, Amban, Fanindi, Tanah Merah, Nimbai, Aimasi, Mokwam, Mimbowi, SP-08, Wosi, and Waseki. Several villages and chosen using snowball sampling method.

Research approach was Participatory situation analysis (PSA) applied to approach livestock farmers (Conroy, 2005). Interviews using questionnaires were done to collect information from whole selected farmers. Queries of 36 opened and closed semi-structured questions were asked to the farmers, i.e. characteristics of the farmers, characteristic of farming performances, and characteristic of cattle production and reproduction performances.Allocated time was around 70 minutes. This field work was done in 15 days.

Parameters used to measure objectives of this study were ages (y),experience (y), household member (head/hh), livelihood, education, work hours, selection, mating sign, pregnant detection, provided forage, grass quality, offered forages, cattle housing, disease knowledge, prevention, utilization, kind of product, herd size, parental stock (head), mating period, forage frequency, sold cattle, and statistic vital consisted of height at withers $(\mathrm{cm})$, body length $(\mathrm{cm})$, heart girth $(\mathrm{cm})$ and body weight $(\mathrm{kg})$.

Qualitative and quantitative data were entered in Excel 2010. Several qualitative data, i.e. livelihood, education, selection, mating sign, pregnant detection up to kind of product were made using coding scales. Classification was based on the three sizes of cattle farming systems in three agroecological zones of Manokwari i.e. coastal, and lowland 
Manokwari. Mathematical formula then was $\mathrm{Y} i j=\mu+\alpha i+\varepsilon i j$, where $\mathrm{Y} i j$ is variable responses. $\mu$ is overall mean, $\alpha i$ is effect of farming system sizes, i.e. 1 is small-scale, 2 is medium-scale and 3 is large-scale cattle farming systems, and $\varepsilon i j$ is errors with normal distribution, $\mathrm{N}$ $(0$, I).Test for data normality was made using KolmogorovSmirnov and Shapiro-Wilk. Data are normally distributed if $\mathrm{p}$-value of tested variables are higher than $0.05(\mathrm{p}>0.05)$.

Analysis of data for normally distributed parameters was made using One-Way Anova (Ott and Longnecker, 2001). Analysis of data using SPPS version 18.0., was used. Data normally distributed were ages of farmers, and price-adult cattle. After test for data normality, several data were found with not normally distributed. Non normality data were livelihood, education, working hours, selection, mating sign, pregnant detection, provided forages, grass quality, offered forages, cattle housing, knowledge diseases, diseases prevention, utilization and kind of product. Each variable was then transformed using Square root (sqrt). The formula of square root (sqrt) transform is $(Y+1 / 2)^{1 / 2}$ which was made to obtain normalityof data. Non parametric data then analyzed using Kruskal-Wallis $(\mathrm{H})$. The formula of KruskalWallis (1952) is equal to $\mathrm{H}=\frac{1}{S^{2}} \times\left[\sum_{i} \frac{R_{i}^{2}}{r_{i}}-\frac{N(N+1)^{2}}{4}\right]$. For knowing which samples were significant difference $(\mathrm{p}<0.05)$, post-hoc analysisusing Scheffewas done (Ott and Longnecker, 2001). Mental model of cattle farming systems were drawn using Microsoft Visio version 15.0.

\section{Results and Discussions}

\subsection{Farmers Performance}

Age of cattle farmers in Manokwari was at productive ages and similar between the scales $(\mathrm{p}>0.05)$. Large-scale farmers might have been raising cattle first followed by medium and small-scales. Therefore they were developed in time. It was also found in experiences. Although not significant ( $p>0.05)$, it was linear with the ages that larger-scale farmers have higher experiences compared to medium and small-scales. Family number living in each household was also similar $(\mathrm{p}>0.05)$. Large-scale farmers had higher number compared to medium and small-scales. In Thailand, most farmers were grouped into moderate livestock farmers (Suppadit et. al., 2006). The ordinary livelihood of the cattle farmers in Manokwari were limited to as farmers and few found making private works. Small shops are commonly found in Manokwari. In general education background of the farmers was in level of elementary school. Education in Thailand had impact on good agricultural practices (GAPs) of cattle farmers in Thailand (Suppadit et. al., 2006). Working time of the farmers allocated to tethered cattle was less than three hours. It means that cattle were released in several communal land and under secondary forest and palm oil trees.

Table 1. Performances of traditional cattle farmers in Manokwari, Papua Barat.

\begin{tabular}{|c|c|c|c|c|c|c|c|c|c|}
\hline \multirow{3}{*}{ Farmers' Performances } & \multicolumn{6}{|c|}{ Scale of groups } & \multirow{2}{*}{\multicolumn{2}{|c|}{ Total $(N=44)$}} & \multirow{3}{*}{$\mathbf{p}$} \\
\hline & \multicolumn{2}{|c|}{ Small $(n=20)$} & \multicolumn{2}{|c|}{ Medium (n=17) } & \multicolumn{2}{|c|}{ Large $(n=7)$} & & & \\
\hline & Mean & SD & Mean & SD & Mean & SD & Mean & SD & \\
\hline Experience $(y)^{1}$ & 10.00 & 5.4 & 13.1 & 5.8 & 14.57 & 7.3 & 11.9 & 6.0 & NS \\
\hline Family (head) ${ }^{1}$ & 4.5 & 1.0 & 4.4 & 1.4 & 5.3 & 1.8 & 4.6 & 1.3 & NS \\
\hline Livelihood $^{2}$ & 1.0 & 0.2 & 1.0 & 0.0 & 1.0 & 0 & 1 & 0.1 & NS \\
\hline Education $^{2}$ & $2.1^{\mathrm{a}}$ & 1.2 & $1.3^{\mathrm{b}}$ & 0.8 & $1.0^{\mathrm{c}}$ & 0 & 1.6 & 1.0 & 0.00 \\
\hline Workingtime (h) & $1.1^{\mathrm{a}}$ & 0.3 & $1.6^{\mathrm{b}}$ & 0.5 & $1.6^{\mathrm{b}}$ & 0.5 & 1.4 & 0.5 & 0.03 \\
\hline \multicolumn{10}{|l|}{ Farmers' knowledge } \\
\hline Selection $^{2}$ & $1.2^{\mathrm{a}}$ & 0.4 & $1.6^{\mathrm{b}}$ & 0.5 & $1.9^{c}$ & 0.4 & 1.5 & 0.5 & 0.00 \\
\hline Mating sign ${ }^{2}$ & 1.9 & 0.3 & 1.8 & 0.3 & 2.0 & 0.0 & 1.9 & 0.2 & NS \\
\hline Pregnant Detection ${ }^{2}$ & 1.3 & 0.5 & 1.2 & 0.4 & 1.1 & 0.4 & 1.2 & 0.4 & NS \\
\hline Grass Quality $^{2}$ & 1.6 & 0.5 & 1.7 & 0.4 & 2.0 & 0.0 & 1.7 & 0.4 & NS \\
\hline Cattle housing ${ }^{2}$ & 1.1 & 0.2 & 1.1 & 0.2 & 1.0 & 0.0 & 1.1 & 0.2 & NS \\
\hline Disease knowledge $^{2}$ & 1.2 & 0.4 & 1.1 & 0.3 & 1.1 & 0.4 & 1.2 & 0.4 & NS \\
\hline Diseases prevention $^{2}$ & 1.7 & 0.5 & 1.7 & 0.5 & 1.3 & 0.5 & 1.6 & 0.5 & NS \\
\hline Utilization $^{2}$ & $1.1^{\mathrm{a}}$ & 0.2 & $1.5^{\mathrm{b}}$ & 0.5 & $1.3^{\mathrm{c}}$ & 0.5 & 1.2 & 0.4 & 0.01 \\
\hline Kind of product ${ }^{2}$ & 1.1 & 0.2 & 1.3 & 0.7 & 1.0 & 0.0 & 1.1 & 0.5 & NS \\
\hline
\end{tabular}

${ }^{1)}$ Anova (F-test), $\mathrm{p}<0.05,{ }^{2)} \mathrm{NPar}$-test $=$ Kruskal-Wallis $(\mathrm{H}), \mathrm{p}<0.05$. NS: Not Significant. Different superscripts indicated significant difference at $\mathrm{p}<0.05$.

Selection of the cattle as breed was not almost done by farmers. Identification of mating time was also very limited only in few farmers as well as pregnant detection. The knowledge of farmers in raising cattle had notsufficient enough as recruited in management of livestock.
Some farmers applied offered forages for cattle and most cattle farmers did not provide forages.

The quality of grasses planted by farmers had low nutrient contents. Semi-natural grasses have low nutrient contents (Niemela et. al., 2008). Experiences shown by 
Central Java's farmers using paddy leaves. They were then made improvement by applying ammonization and fermentation for increase nutrient quality of paddy leaves (Nurcholidah et. al., 2013; Muslim, 2006). Cattle farming systems in Manokwari have been kept mostly without houses, free-range cattle farming systems. It is similar in Kenya as reported by Ohaga et. al., (2007). Cattle farmers had no sufficient knowledge in livestock diseases. While in Kenyan as reported by Ohaga et. al. (2007), diseases of livestock was Trypanosomosis, East Coast Fever, Anasplasmosis, Helminthosis, Anthrax, Food and Mouth Disease. However, Helminthosis could have huge infestation under tropical systems in Indonesia. Therefore, prevention of diseases had seldom done. Kenyan farmers had recognized diseases compared to West Papuan farmers. Utilization of cattle were done by selling and drought animal. Cattle have been seldom used as animal traction. In contrary, Kenyan livestock farmers have been intensively using cattle as animal traction (Ohaga et. al., 2007). Kind of cattle products in Manokwari were meat, skin and feces.Skin was processed as fast food (in Bahasa called Kerupuk). Bio-fuel was extensively applied by many farmers in Papua (Widodo and Hendriadi, 2005). Other utilization of cattle product is bio-fertilizer which was intensively applied by crop farmers in Upland (Thanner et al., 2001), Middle Java (Nurcholidah et. al., 2013) and as well as Mid-Hill Nepal (Thanner and Tanner, 2002).

\subsection{Cattle Performance}

Herd size of cattle raised by farmers in Manokwari was significant difference $(p<0.000)$. Small-scale farmers in average had only kept $2.5 \pm 0.9$ head/hh. In one hand, medium and large-scale cattle farmers had doubled subsequently, i.e. $6.5 \pm 0.8 \mathrm{head} / \mathrm{hh}$ and $12.9 \pm 1.6 \mathrm{head} / \mathrm{hh}$. Bali cattle werea commonly local breed introduced and raised in West New Guinea Papua. The herd size kept by farmers in Manokwari was lower than in Jawa Tengah/Centre of Java (Nurcholidah et. al., 2013), i.e.14.6 livestock unit. In the Mid-Hill Nepal herd size in terms of Tropical Livestock Unit was 4-6 unit (Thorne and Tanner, 2002). Widayati and Suawa (2007) grouped cattle farmers in Sarmi-Papua into three classes, i.e. farmer with keeping cattle 1-2 head/hh, 3-6 head/hh and 7-10 head/hh. In Thailand farm size become significant component determining cattle performance (Suppadit et. al., 2006). In Kenya as reported by Ohaga et. al. (2007), livestock herd size was relatively varied, i.e. 2-23 head/hh (median of 2).

Table 2. Cattle performances in Manokwari, Papua Barat.

\begin{tabular}{|c|c|c|c|c|c|c|c|c|c|}
\hline \multirow{3}{*}{$\begin{array}{l}\text { Performance } \\
\text { Cattle }\end{array}$} & \multicolumn{6}{|c|}{ Scale of groups } & \multirow{2}{*}{\multicolumn{2}{|c|}{ Total $(\mathrm{N}=\mathbf{4 4})$}} & \multirow{3}{*}{$\mathbf{p}$} \\
\hline & \multicolumn{2}{|c|}{ Small $(n=20)$} & \multicolumn{2}{|c|}{ Medium (n=17) } & \multicolumn{2}{|c|}{ Large $(n=7)$} & & & \\
\hline & Mean & SD & Mean & SD & Mean & SD & Mean & SD & \\
\hline Herd size $\left(\right.$ head) ${ }^{1}$ & $2.5^{\mathrm{a}}$ & 0.9 & $6.5^{\mathrm{b}}$ & 0.8 & $12.9^{\mathrm{c}}$ & 1.6 & 5.7 & 3.8 & 0.00 \\
\hline Parental stock (head) ${ }^{1}$ & 2.4 & 0.3 & 2.3 & 0.2 & 2.7 & 0.1 & 2.4 & 0.3 & NS \\
\hline Mating period $(\mathrm{d})^{1}$ & 66.7 & 17.32 & 69 & 22.4 & 56.4 & 16.8 & 65.9 & 19.4 & NS \\
\hline Forage freq(times $)^{1}$ & 2.4 & 0.5 & 2.3 & 0.5 & 2.6 & 0.5 & 2.4 & 0.5 & NS \\
\hline Offered Forages $^{2}$ & $1.1^{\mathrm{a}}$ & 0.2 & $1.1^{\mathrm{b}}$ & 0.2 & $2.0^{\mathrm{c}}$ & 0.0 & 1.2 & 0.4 & 0.00 \\
\hline
\end{tabular}

${ }^{1)}$ Anova (F-test), $\mathrm{p}<0.01$, NS: Not Significant. Different superscripts indicated significant difference at $\mathrm{p}<0.05$.

Parental stock of the cattle kept by farmers in Manokwari was slightly similar amongst the three scales $(\mathrm{p}>0.05)$, i.e. 2 livestock unit. Parental stock becomes much more important in designing future livestock development in Indonesia (Ilham, 2007). This should be done to improve genetically quality cattle. Mating period of cattle entering reproduction cycle was similar between the three systems $(p>0.05)$. Forage frequency was practiced similar in the whole cattle farming scales $(p>0.05)$. Due to free-range cattle farming systems adopted by traditional cattle farmers, forages offered to the cattle were less than that expected. Tropical forages grown commonly under agro-ecological zones in Manokwari were Themeda arguens, Paspalum conjugatum, Digitaria sp, Imperata cylindrica, Cyperus rotundus dan Eleusine indica. Wastes from agricultural crops should be utilized as applied by cattle farmers in East Java (Winarso et. al., 2005). Therefore alternative forages should be prepared for the cattle such as reported by Kusnadi, (2008), Devendra and Sevilla, (2002) in Asia. Cattle farming system in West New Guinea needs some improvement. Nulik and Hau (2005) in East Nusa Tenggara had shown their research for improving local forages to high quality nutrient. Local forages applied were Glirisedia sepium, Leucaena leucocephala and Sesbania glandiflora. Those forages were made in the shapes of cube and pellet. The cube was the preferred one compared to pellet with sufficient nutrient quality. Best practices applying forages for livestock was reported in East Java (Anggraeni et. al., 2006; Anggraeni et. al., 2008). Therefore, Bahri (2004) recommended several issues to be promoted for improving cattle farming systems in Indonesia, i.e. breeds, feeds, policy, veterinary and food security and postharvesting. Theses underlined issues were also suggested by Ilham (2007), national livestock feeds and cattle breeds.

\subsection{Economical Performances}

Agribusiness of cattle farms was measured in net benefits earned by cattle farmers. The calves, weaned calves, grower and adult cattle were varied sold. The prices of young steer cattle were in the ranges of 4 to 5 million rupiahs (US\$400- 
500).The prices of young heifer grower cattle were in the ranges of 4 (US\$410-470). In Indonesia the prices are made based commonly on the simple mathematical formulae, i.e.
Cattle prices $=$ weight of cattle $\times 0.50 \times$ the prices per $\mathrm{kg}$ meat.

Table 3. Agribusiness of traditional cattle farming system in Manokwari, Papua Barat.

\begin{tabular}{|c|c|c|c|c|c|c|c|c|c|}
\hline \multirow{3}{*}{$\begin{array}{l}\text { Economic } \\
\text { Performance(IDR)* }\end{array}$} & \multicolumn{6}{|c|}{ Scale of groups } & \multirow{2}{*}{\multicolumn{2}{|c|}{ Total $(N=44)$}} & \multirow{3}{*}{$\mathbf{p}$} \\
\hline & \multicolumn{2}{|c|}{ Small $(n=20)$} & \multicolumn{2}{|c|}{ Medium $(n=17)$} & \multicolumn{2}{|c|}{ Large $(n=7)$} & & & \\
\hline & Mean & SD & Mean & SD & Mean & SD & Mean & SD & \\
\hline Male calf ${ }^{1}$ & 5352000 & 949720 & 5264700 & 615360 & 4785710 & 128637 & 5215900 & 898300 & NS \\
\hline Female calf $^{1}$ & 4125000 & 930120 & 4794110 & 662820 & 4357140 & 110733 & 4420450 & 901280 & NS \\
\hline Young steer $^{1}$ & 1190000 & 335449 & 1129411 & 211437 & 1114285 & 260950 & 1154545 & 277408 & NS \\
\hline Young heifer $^{1}$ & 8900000 & 836660 & 8794110 & 685990 & 8928570 & 838080 & 8863630 & 765260 & NS \\
\hline Adult steer ${ }^{1}$ & 1925000 & 410231 & 2058823 & 511198 & 1714285 & 367099 & 1943181 & 452074 & NS \\
\hline
\end{tabular}

${ }^{1)}$ Anova (F-test), $\mathrm{p}<0.05, \mathrm{p}<0.05$. NS: Not Significant. *IDR.10.000=USD 1.

No differences $(p>0.05)$ were found in prices of sold cattle in Manokwari. It means that the prices of sold cattle in Manokwari were very much controlled by the farmers and the middle men. Middle man had high benefit compared to cattle farmers (Widayati and Suawa, 2007). Although, it is traditional market, the farmers and buyers were put many effort to keep cattle prices.Similar information was also reported by Priyanti et. al. (1997) in Lampung. The small-scale cattle farms tend to sell cattle in high prices to gain fresh money as capitals for farm continuity. While the other two cattle farming were lower than that of small-scale. It is therefore, Adnyana (2000) cited by Sudaryanto and Jamal (2000) developed agribusiness of cattle in Indonesia. Other record of economical aspect was informed by Winarso et. al. (2005) in Eastern Java-Indonesia. Income from beef raising cattle had significant impact on good agricultural practices (GAPs) in Thailand (Suppadit et. al., 2006). Good agricultural practices were also successful experienced by South Sulawesi's farmers (Basuno and Sehaeti, 2007). They said that GAPs are very much determined by available and ready human resources capacities. In conclusion of Winarso et. al. (2005), integration of livestock and farm agribusiness is the success story of beef cattle development in East Java.

\section{Conclusions}

Farmers performances will have severe determinant factor in shaping cattle farming system. Integration of livestock with farming business needs further collaboration. Breeds and feeding are the first two components for further improvement. Forages with low nutrient content would need feeding technology such as ammonization and fermentation. Good Agriculture Practices (GAPs) will be determined by available and capability of human resources. Extension is a small technical aspect that need further activities run under traditional cattle farming systems.

\section{Acknowledgment}

Authors thanked Dadan, S. Pt. for sharing data of cattle performances in Manokwari. Special thanks were given to the whole cattle farmers as participants during field visits in several villages both in coastal and lowland agro-ecological zones of Manokwari.

\section{References}

[1] Anggraeni, Y. N., U. Umiyasih, D. Pamungkas dan Aryogi. 2006. Potensi bahan pakan Inkonvensional Asal Limbah Pertanian dan Perkebunan di Beberapa Kabupaten di Jawa Timur. Seminar Nasional Teknologi Peternakan dan Veteriner. Hal.: 891-899.

[2] Anggraeni, Y. N. dan U. Umiyasih. 2008. Evaluasi Potensi Pakan Asal Limbah Tanaman Pangan dan Limbah Perkebunan di Daerah Prioritas Kawin Alam Pendukung Program P2SDS. Seminar Nasional Teknologi Peternakan dan Veteriner. Hal. 304-311.

[3] Bahri, S., B. Setiadi, I. Inounu. 2004. Arah penelitian dan pengembangan Peternakan Tahun 2005-2009. Seminar nasional teknologi peternakan dan veteriner 2004. P. 6-10.

[4] Basuno, E. and R.N. Suhaeti. 2007. Analisis bantuan pinjaman langsung masyarakat (BPLM); kasus pengembangan usaha ternak sapi di provinsi Sulawesi Selatan. Analisis kebijakan pertanian. Vol 5. No. 2., Juni 2007.p: 150-166.

[5] Bradford, G.E. 1999. Contribution of animal agriculture to meeting global human food demand. Livestock production science 59 (1999) 95-112.

[6] Conroy, C. 2005. Participatory livestock research; a Guide. ITDG publishing. Warwickshire. UK.

[7] Devendra, C. 2007. Perspectives on animal production systems in Asia. Livestock science 106 (2007) 1-18.

[8] Devendra, C. and C.C. Sevilla. 2002. Availability and use of feed resources in crop animal systems in Asia. Agricultural systems 71 (2002) 59-73.

[9] Devendra, C. and D. Thomas. 2002. Smallholder farming systems in Asia. Agricultural systems 71 (2002) 17-25.

[10] Diwyanto, K., B. R. Prawiradiputra dan D. Lubis. 2001. Integrasi Tanaman Ternak dalam Pengembangan Agribisnis yang Berdaya Saing, Berkelanjutan dan Berkerakyatan. Seminar Nasional Teknologi Peternakan dan Veteriner 2001. Hal.: 17-26. 
[11] Hartono, S. and T.W. Widayati. 2013. An alternative approach to meet beef self-sufficiency in West Papua. J. Indonesian Trop. Anim. Agric. 36 (3) September. Diponegoro University, Semarang.

[12] Ilham, N. 2007. Alternatif kebijakan peningkatan pertumbuhan PDB Subsektor peternakan di Indonesia. Analisis kebijakan pertanian. Vol. 5. No. 4. Desember 2007. Hal.: 335-357.

[13] Indraningsih, R. Widyastuti, Y. Sani. .... Limbah Pertanian dan Perkebunan Sebagai Pakan Ternak; Kendala dan Prospek. Lokakarya Nasional Ketersediaan IPTEKS dalam pengendalian penyakit strategis pada ternak ruminansia besar. Hal.: 99-105.

[14] Iyai, D.A. dan H. Y. Chrisostomus. 2013. Scoping, Pemodelan dan Kuantifikasi Sistim-Sistim Peternakan Terpadu di Manokwari, Papua Barat. Laporan Penelitian. Fakultas Peternakan Perikanan dan IlmuKelautan. UniversitasNegeri Papua. Manokwari.

[15] Kusnadi, U., S. Iskandar, dan M. Sabrani. 1993. Research methodology for crops-animal systems in Hilly Areas of Indonesia. (Ed). C. Devendra dan C. Sevilla. Proceedings of an International Workshop. Crop-Animal Interaction. IRRI Discussion Paper Series No. 6. IRRI Philippines.

[16] Kusnadi, U. 2008. Inovasi teknologi peternakan dalam sistim integrasi tanaman-ternak untuk menunjang swasembada daging sapi. Jurnal pengembangan inovasi pertanian. 1 (3): 189-205.

[17] Muslim, C. 2006. Pengembangan sistim integrasi padi-ternak dalam upaya pencapaian swasembada daging di Indonesia: Suatu tinjauan evaluasi. Analisis kebijakan pertanian. Vol. 4. No. 3. September 2006. Hal. 226-239.

[18] Niemela, M., A. Huuskonen, S. Jaakola, E. Joki-Tokola, and M. Hyvarinen. 2008. Coastal meadows as pastures for beef cattle. Agriculture, Ecosystem and Environment 124 (2008) 179-186.

[19] Nulik, J., D.K. Hau. 2005. Pembuatan dan pemanfaatan pakan awet pada ternak sapi bali timor. Seminar nasional teknologi peternakan dan veteriner 2005 .

[20] Nurcholidah, A. Sodiq, K. Muatip. 2013. Kinerja usaha peternakan sapi potong sebelum dan setelah mengikuti program Sarjana Membangun Desa Periode 2008-2012. Jurnal ilmiah peternakan 1 (3): 1183-1191.
[21] Ohaga, S.O., E.D. Kokwaro, I.O. Ndiege, A. Hassanali, R.K. Saini. 2007. Livestock farmer's perception and epidemiology of bovine trypanosomiasis in Kwale District, Kenya. Preventive veterinary medicine. 80 (2007) 24-33.

[22] Ott, R.L. and M. Longnecker. 2001. An introduction to statistical methods and data analysis. $5^{\text {th }}$ Edition.Texas A \& M University. Wadsworht Group USA.

[23] Priyanti, A., T.D. Soedjana, R. Matondang, P. Sitepu. 1997. Estimasi sistim permintaan dan penawaran daging sapi di provinsi Lampung. Jurnal Ilmu Ternak dan Veteriner. Vol. 3. No.2. Tahun 1998.

[24] Sudaryanto, T. dan E. Jamal. 2000. Pengembangan agribisnis peternakan melalui pendekatan Coorporate Farming untuk mendukung ketahanan pangan nasional. Seminar nasional peternakan dan veteriner. p: 35-47.

[25] Supriadi, H. 2008. Strategi kebijakan pembangunan pertanian di Papua Barat. Analisis kebijakan pertanian. Vol. 6 No. 4.Desember 2008: 352-377.

[26] Suppadit, T., N. Phumkokrak, P. Poungsuk. 2006. Adoption of Good Agriculture Practices For Beef Cattl Farming of Beef cattle raising farmers in Tambon Hindard, Dan Khunthot District, Nakhon Rachasima Province, Thailand. KMITL. Sci. Tech. J. Vol. 6. No.2. Juli-Des. 2006.

[27] Tanner, P.J., S.J. Holden, E. Owen, M. Winugroho, M. Gill. 2001. Livestock sustaining intensive smallholder crop production through traditional feeding practices for generating high quality manure-compost in Upland Java. Agriculture, Ecosystems and Environment. 84 (2001) 21-30.

[28] Thorne, P.J. and C.J. Tanner. 2002. Livestock and nutrient cycling in crop animal systems in Asia. Agricultural systems 71 (2002) 111-126.

[29] Utomo, B.N. and E. Widjaja. 2007. Integrasi ternak sapi bali dengan perkebunan kelapa sawit; 1. Introduksi teknologi inseminasi buatan dan sinkronisasi estrus untuk meningkatkan reproduktifitas ternak. Seminar nasional teknologi peternakan dan veteriner.

[30] Widayati, T.W. and E. K. Suawa. 2007. Pengembangan agribisnis peternakan sapi potong melalui perbaikan manajemen mikro di kabupaten Sarmi-Papua. Seminar nasional teknologi peternakan dan veteriner. 